\title{
Clobazam as an Add-on Drug in the Treatment of Refractory Epilepsy of Childhood
}

\author{
D.L. Keene, S. Whiting and P. Humphreys
}

\begin{abstract}
We report the results of a double-blind cross-over study comparing clobazam and placebo in the treatment of refractory childhood epilepsy. Fifty-two percent of patients had greater than $50 \%$ reduction in their seizure frequency when taking the clobazam. During the placebo phase no patient recorded a greater than $50 \%$ reduction in seizure frequency. Sex, age, seizure type, intellect did not appear to differentiate clobazam responsive from nonresponsive patients. Only $2 / 21$ patients had behavioral changes on the drug sufficiently severe to require the patient to drop out of the study prematurely. Drug interactions between clobazam and the other anticonvulsant medicines did not occur.

RÉSUMÉ: Le clobazam comme traitement d'appoint dans l'épilepsie réfractaire de l'enfance Nous rapportons les résultats d'une étude à double-insu en chassé-croisé comparant le clobazam et un placebo dans le traitement de l'épilepsie réfractaire de l'enfance. Cinquante deux pourcent des patients ont eu une diminution de la fréquence des crises de plus de $50 \%$ sous clobazam. Pendant la phase placebo, aucun patient n'a eu une réduction de la fréquence des crises de plus de $50 \%$. Le sexe, l'âge, le type de crises, le niveau intellectuel ne semblent pas distinguer les répondeurs des non-répondeurs au clobazam. Seulement 2 patients sur 21 ont eu des modifications du comportement assez sévères pour motiver une sortie d'étude anticipée. Il n'y a pas eu d'interaction médicamenteuse entre le clobazam et les autres médicaments anticonvulsivants.
\end{abstract}

Can. J. Neurol. Sci. 1990; 17:317-319

A number of studies using the 1,5 benzodiazepine, clobazam, in the treatment of refractory epilepsies of childhood have been reported. 1,2,3,4 Most of these studies were open trials using large numbers of patients. Seizures were observed to disappear or be reduced in $60-70 \%$ of patients taking the drug. All seizure types appeared to be responsive. The drug dosage used in these trials varied from $0.1 \mathrm{mgm} / \mathrm{kg} /$ day to $2.5 \mathrm{mgm} / \mathrm{kg} /$ day. Over a period of time however, a significant number of patients developed tolerance. This seemed to occur earlier in those patients who received a higher drug dosage per kilogram body weight per day $(\mathrm{mg} / \mathrm{kg} /$ day $) .{ }^{4}$ Side effects were infrequent and consisted for the most part of behavioural changes, sedation and/or increased drooling. From this literature review of mainly open trials, it would appear that clobazam is an effective add-on drug in all of the refractory seizure disorders of childhood. This paper reports the findings of a double-blind cross-over study using clobazam in this patient group.

\section{METHOD}

To test the hypothesis that clobazam would be an effective add-on drug in the treatment of medically refractory epilepsy of childhood, a double-blind cross-over study was done. Patients who were enrolled in this study had to have parental consent; be between 6 months and 18 years; and have greater than 4 seizures per month. They were excluded if they had a degenerative central nervous system disorder, brain tumor, or past history of poor drug compliance.

This study was divided into two parts with one month prestudy period in which the patients recorded their seizure type, frequency and duration on a seizure record sheet. As well, baseline anticonvulsant drug levels, complete blood count (CBC), platelet count, blood urea nitrogen (BUN), aspartate aminotransferase (AST), creatinine, blood glucose, thyroid stimulating hormone (TSH), T4, T3, and electroencephalogram (EEG), were done. Where needed the patients had their anticonvulsant drug dosages adjusted to bring their serum drug levels into "therapeutic range". If their seizures continued despite this, they were entered into the study. Patients on another benzodiazepine were tapered off this drug before being entered into the pre-study period.

At the end of the pretrial phase, and after a signed parental consent had been obtained, patients were randomly assigned into the placebo or the trial drug group. This was done by the hospital pharmacy without the patient, physician or dispensing pharmacist being aware of which group the patient had entered.

From the Section of Neurology, Department of Pediatrics, Childrens Hospital of Eastern Ontario, Ottawa

Received February 2, 1990. Accepted in final form May 14, 1990

Reprint requests to: Dr. Daniel L. Keene, Section of Neurology, Department of Pediatrics, Childrens Hospital of Eastern Ontario, 401 Smyth Rd., Ottawa, Ontario, Canada K1H 8Ll 
A master code list was kept in the pharmacy which could be broken if problems arose during the study. Breaking of the patient's code was done by the pharmacist at the request of the treating physician. Such a patient was considered a failure and included in the analysis as such along with the reason.

The dosage of the drug (placebo or clobazam) to be taken was calculated based on the patient's weight so that he/she received $0.5 \mathrm{mg} / \mathrm{kg} / \mathrm{day}$ at the onset of the trial. If a clinical response was not seen in the first month of phase two, the dosage was increased to $1.0 \mathrm{mg} / \mathrm{kg} /$ day providing no clinical side effects were reported by the parents or patient. If the patient had excessive drowsiness the dosage was decreased by $0.25 \mathrm{mg} / \mathrm{kg} / \mathrm{day}$ at that time regardless of the level of seizure control.

Patients remained in phase one for three months with monthly visits to the clinic. During such visits the seizure record sheet was reviewed and new sheets were given to the parents for the next month's recording. A side effects record sheet was also reviewed at each clinic visit. At the end of phase 2 the patient had a repeat EEG, CBC, Platelet count, AST, BUN, TSH, T-4, T-3, Creatinine, Blood Glucose, and Serum Anticonvulsant Level determination(s).

Patients began phase two with a slow changeover of one month's duration in order to prevent the possibility of withdrawal seizures. During this time the new study medicine was added while the previous study drug was phased out. This period was not included in the analysis of data. Patients were then maintained on the new "drug" in a similar fashion to phase 2. At the end of the eighth month, EEG, CBC, Platelets, BUN, TSH, T-4, T-3, Creatinine, AST, Blood Glucose, and Anticonvulsant Drug Levels were repeated. At this point the code was broken. Improved patients were offered the opportunity to begin long term maintenance therapy with clobazam.

Compliance was measured during the study by means of a pill count done at each visit.

Table 1: Group Characteristics after Randomization

\begin{tabular}{|c|c|c|c|}
\hline & Total & $\begin{array}{c}\text { Group A } \\
\text { (Placebo- } \\
\text { Clobazam) }\end{array}$ & $\begin{array}{c}\text { Group B } \\
\text { (Clobazam- } \\
\text { Placebo) }\end{array}$ \\
\hline NUMBER & 21 & 10 & 11 \\
\hline $\begin{array}{l}\text { SEX } \\
\text { - Female } \\
\text { - Male }\end{array}$ & $\begin{array}{l}10 \\
11\end{array}$ & $\begin{array}{l}6 \\
4\end{array}$ & $\begin{array}{l}4 \\
7\end{array}$ \\
\hline $\begin{array}{l}\mathrm{AGE} \\
\text { - Mean } \\
\text { - Range }\end{array}$ & $\stackrel{11}{2-19} \mathrm{Yrs}$. & $\begin{array}{c}11.4 \\
2-18 \text { Yrs. }\end{array}$ & $\begin{array}{c}10 \\
3-19 \text { Yrs. }\end{array}$ \\
\hline $\begin{array}{l}\text { SEIZURES } \\
\text { - Generalized } \\
\text { - Partial } \\
\text { - Partial Generalized }\end{array}$ & $\begin{array}{r}13 \\
6 \\
2\end{array}$ & $\begin{array}{l}7 \\
2 \\
1\end{array}$ & $\begin{array}{l}6 \\
4 \\
1\end{array}$ \\
\hline $\begin{array}{l}\text { INTELLECT } \\
\text { - Normal } \\
\text { - Abnormal }\end{array}$ & $\begin{array}{r}4 \\
17\end{array}$ & $\begin{array}{l}1 \\
9\end{array}$ & $\begin{array}{l}3 \\
8\end{array}$ \\
\hline $\begin{array}{l}\text { CENTRAL NERVOUS S } \\
\text { - Normal } \\
\text { - Abnormal }\end{array}$ & $\begin{array}{r}13 \\
8\end{array}$ & $\begin{array}{l}5 \\
5\end{array}$ & $\begin{array}{l}8 \\
3\end{array}$ \\
\hline $\begin{array}{l}\text { DOSAGE } \\
\quad \text { - Mean }(\mathrm{mgm} / \mathrm{kg}) \\
\text { - Range }(\mathrm{mgm} / \mathrm{kg})\end{array}$ & $.2-1.3^{.64}$ & .60 & $\begin{array}{c}.64 \\
.2-1.0\end{array}$ \\
\hline SUCCESSES & $11 / 21$ & $5 / 10$ & $6 / 11$ \\
\hline
\end{tabular}

During the study dosages of other anticonvulsant medications the patient had been taking before entry into the study were modified in order to maintain blood levels within respective therapeutic ranges.

A drug success was stated to have occurred if the patient had a $50 \%$ or more reduction in seizure frequency when on the drug in comparison to the pretrial and placebo phases of the study. Patients who had to drop out of the study because of side effects while on clobazam were considered as drug failures even if a $50 \%$ reduction in seizure frequency occurred. The percentage of responders to nonresponders was calculated.

The calculation of patient number was based on an expected number of successes for this drug (according to the literature) of approximately $60 \%$. The expected percentage of children with refractory seizures who might stop having seizures spontaneously during an 8-month period was assigned a 10\% figure. In order to see a significant difference between the groups a $p$ value of 0.05 was chosen. The number of patients felt necessary to confirm the study hypotheses was calculated to be twenty.

\section{RESULTS}

Twenty-one patients met the criteria for entry into this study ( 10 males and 11 females). Their ages ranged from 2 to 19 years with a mean age of 11 years. Thirteen patients had generalized seizures; 6 had partial seizures; 2 had partial seizures with secondary generalization. Four patients were of normal intellect, while 17 had varying degrees of mental retardation. With the exception of mental status, examinations of the central nervous system were normal in 13 patients - with the remainder having varying degrees of motor difficulties (i.e., spastic quadraparesis, hemiplegia or diplegia).

After randomization into treatment groups, 10 patients received placebo then clobazam, while 11 patients received clobazam then placebo. No differences between the two groups as to age, sex, seizure type, intellectual ability or findings on the examination of the nervous system were noted. The mean drug dosage as expressed in $\mathrm{mg} / \mathrm{kg} /$ day was not different between the two patient treatment groups (Table 1).

Eleven patients $(52 \%)$ had a significant reduction $(50 \%$ or greater) in their seizure frequency without significant side effects while taking clobazam. No patients had a significant reduction in their seizure frequency when in the placebo phase. As well, no patients had an increase in their seizure frequency while taking clobazam. Two patients had to withdraw during the clobazam phase because of severe behavioural changes which did not respond to lowering the drug dosage.

When the patients who had a successful outcome on clobazam versus those with a non-successful outcome were compared, no differences could be found with respect to sex, age, intellectual level, findings on examination of the nervous system, order in which they were randomized or initial electroencephalographic findings. Patients with partial seizures tended to respond better to clobazam than did those with generalized seizures, but numbers in each seizure group were small. The difference in the mean daily clobazam dosage between the responder $(0.75 \mathrm{mg} / \mathrm{kg})$ and nonresponder $(0.65 \mathrm{mg} / \mathrm{kg})$ groups was not significant (Table 2).

No abnormal values for complete blood count, platelet count, urea, creatinine, glucose, ALT, TSH, T-4 or T-3 occurred during 
Table 2: Comparison of Clinical Variables for Patients With Successful Outcome on Clobazam Versus Patients Without Successful Outcome

\begin{tabular}{|c|c|c|c|}
\hline Variable & Total & Success & Non-Success \\
\hline NUMBER & 21 & 11 & 10 \\
\hline $\begin{array}{l}\text { SEX } \\
\quad \text { - Male } \\
\text { - Female }\end{array}$ & $\begin{array}{l}10 \\
11\end{array}$ & $\begin{array}{l}5 \\
6\end{array}$ & $\begin{array}{l}5 \\
5\end{array}$ \\
\hline $\begin{array}{l}\text { AGE } \\
\quad \text { - Mean } \\
\text { - Range }\end{array}$ & $\begin{array}{c}11 \\
2-19 \text { Yrs. }\end{array}$ & $\begin{array}{c}12.5 \\
3-18 \text { Yrs. }\end{array}$ & $\begin{array}{c}9.5 \\
2-19 \text { Yrs. }\end{array}$ \\
\hline $\begin{array}{l}\text { SEIZURES } \\
\text { - Generalized } \\
\text { - Partial* } \\
\text { - Partial Generalized }\end{array}$ & $\begin{array}{r}13 \\
6 \\
2\end{array}$ & $\begin{array}{l}6 \\
5 \\
0\end{array}$ & $\begin{array}{l}7 \\
1 \\
2\end{array}$ \\
\hline $\begin{array}{l}\text { INTELLECT } \\
\text { - Normal } \\
\text { - Abnormal }\end{array}$ & $\begin{array}{r}4 \\
17\end{array}$ & $\begin{array}{l}3 \\
8\end{array}$ & $\begin{array}{l}1 \\
9\end{array}$ \\
\hline $\begin{array}{l}\text { CENTRAL NERVOUS S } \\
\text { - Normal } \\
\text { - Abnormal }\end{array}$ & $\begin{array}{r}13 \\
8\end{array}$ & $\begin{array}{l}9 \\
2\end{array}$ & $\begin{array}{l}4 \\
6\end{array}$ \\
\hline $\begin{array}{l}\text { DOSAGE } \\
\text { - Mean }(\mathrm{mgm} / \mathrm{kg}) \\
\text { - Range }(\mathrm{mgm} / \mathrm{kg})\end{array}$ & $.2-1.3$ & $.2-1.3$ & $\begin{array}{c}.65 \\
.4-0.8\end{array}$ \\
\hline
\end{tabular}

*p less than 0.05

this study. Symptomatic inter-reactions between clobazam and the other concomitant anticonvulsant medications did not occur. Concomitant anticonvulsant medication did not need to be changed in order to maintain "therapeutic levels" during the duration of this study.

All 11 patients who had shown a successful outcome during the clobazam phase of the drug entered the long term phase of the study. After 2 years on the drug, only 2 have experienced an increase in seizure frequency. These patients had the drug withdrawn over a 2-month period of time without a major increase in seizure frequency. After a drug holiday of 2 to 3 months, the clobazam was restarted with a good improvement in seizure control, but not to the same degree as originally obtained. No long term side effects have been seen in this group.

\section{Discussion \& CONCLUSION}

In this study, clobazam proved to be a safe and effective addon drug in the treatment of children with medically refractory epilepsy. The rate of responders in this double-blind cross-over study was similar to those rates reported in the open trials. ${ }^{4}$ No drug inter-reactions were seen with the other anticonvulsant drugs taken simultaneously. Tolerance in our study was much less frequent than that reported in the literature. This may have been due to the lower daily dosage of clobazam taken.

The physical and mental characteristics of the patients did not appear to identify those with a greater chance of a satisfactory response to clobazam. Though the numbers of patients in each seizure group were small, a trend to better outcome was seen in clobazam-treated patients having partial seizures. This is in keeping with findings of Guberman et al. 5 Further studies in this area are required to confirm this trend.

Based on the results of our study, we would recommend a trial of clobazam in all children whose epilepsy has proven refractory to standard anticonvulsant medications. When starting a patient on the drug the dose should be low (i.e., $0.5 \mathrm{mg} / \mathrm{kg}$ ) and gradually increased until either control is obtained or side effects occur. By using this approach, the development of drug tolerance might be avoided.

\section{REFERENCES}

1. Gastaut H, and Low M. Antiepileptic properties of clobazam, a 1,5 benzodiazepine in man. Epilepsia 1979; 20: 437-446.

2. Gastaut H. The effects of benzodiazepines on chronic epilepsy in man (with particular reference to clobazam). In: Hindmarch I, Stonier PD, eds. Clobazam International Congress and Symposium Series. London: Royal Society of Medicine 1981; 43: $141-446$.

3. Farrell K. Benzodiazepines in the treatment of children with epilepsy. Epilepsia 1986; 27 (Suppl 1): S45-52.

4. Koeppen D. A review of clobazam studies in epilepsy. $I n$ : Hindmarch I, Stonier PD, Trimble MR, eds. Clobazam: Human Psychopharmacology and Clinical Applications. International Congress and Symposium Series, London: Royal Society of Medicine 1985; 74: 159-165.

5. Guberman H, Sherwin A, Blaschuk K. Add-on trial of clobazam in 36 intractable epileptic patients, with plasma level correlations. Can J Neurol Sci 1989; 16: 248 (Abst). 